\title{
COVID-19 SCENARIO AND POSSIBLE CRISIS MANAGEMENT PLAN IN BANGLADESH: A REVIEW
}

\author{
SK Farjana Faruk Nitu, Atif Aninda Rahman and Md. Nazmul Haque* \\ Department of Urban and Regional Planning, Khulna University of Engineering \&Technology, Bangladesh
}

Received: 01 October 2020

Accepted: 07 November 2020

\begin{abstract}
At present novel corona virus (COVID-19) has affected 213 countries around the world. In the context of both developing and less developed countries, it has proven to be fatal. Bangladesh, being a country of low-middleincome economy is still experiencing daily rise of COVID-19 cases. This study investigates the impact of COVID-19 on some important sectors of the country, where the education system is in danger as well as the lion's share of the inhabitant cascade with poverty. The outcome of the research also states the overall management system has not worked smoothly in the pandemic situation. It focused on the existing emergency crisis response management plan, policy framework and parliamentary organizations of Bangladesh which are not good enough to battle a pandemic such as COVID-19. The secondary data were collected from different credential sources. This research mainly focused on the in-depth analysis of crisis during this time and highlighted the crisis sector management of Bangladesh. Hence, it formulated a proposal on 10 sector-based (education, economic, general public, victim, Government, private sector, defense, medical services, media, social value perception) Crisis Response Management Technique and a committee that would work in post COVID-19 time in Bangladesh. In future, this research and its policy frame work would help the government to allocate the budget for different sectors not only for pandemic situation but also for another crisis and help minimize its catastrophe.
\end{abstract}

Keyword: Corona viruses (COVID-19); economic crisis; education crisis; crisis Respondent Sector; crisis Response Management.

\section{INTRODUCTION}

The pandemic situation has gathered all the communities of the whole world under one roof and mounted a common problem among all the peoples of the world. Not limited to a certain geographical area the entire world is now a breeding palace for the COVID-19 virus. People struggling to cope with this pandemic on a daily basis can easily understand the gravity of the current situation and knows how much imperative it is to address solutions and alternatives to this problem. The alternatives discussed in this research will be able to address the indirect issues of pandemic not only this but also the future problems regarding health issues which ultimately extends up to the social and economic issues also. The policy guidelines set here will lead to a feasible solution for further problems that may arise. Covid-19 has both directly and indirectly influenced the lifestyle of people and the society. The government of Bangladesh adopted policies and framework keeping only a single scenario in mind. Whereas, the pandemic situation covers are vast syllabus of direct and indirect consequences. The research has been based on keeping this problem in mind and also will enable to tackle any further problems that may arise in any pandemics in the near future.

Within the city of Wuhan, the capital of Hubei territory in the People's Republic of China new respiratory infection was detected at the end of 2019 triggered by severe acute respiratory syndrome corona virus 2 (SARSCov-2) (Salihu et al., 2020). World Health Organization named this contamination Corona virus disease-19 (COVID-19) and announced it to be a pandemic (World Health Organization, 2020). The RNA sequence of this closely matches to two bat corona viruses and it appears likely that the bat is the essential source of this infection (Perlman, 2020).

The worldly spread and dispersion of COVID-19 has produced a prompt imperative mindset in the medical and health personnel's which includes constant monitoring, screening, maintaining social distancing, restrictions in movement and medical care and instructions for the affected and isolated (Berger et al., 2020). Different countries are of the world already have taken necessary steps and has undertaken policies against the virus. Different types of support packages have been offered in different countries (Zabala, 2020). Bangladesh government has also taken rapid immediate steps to tackle the situation. Different types of financial aids and support packages were being provided by the government of Bangladesh (KPMG, 2020). The policy plans taken all are based on and build upon the mindset of tackling the current scenario and curtailing down the losses that have been incurred due to the virus. Very less thought has been given on the policy measures of the next pandemic or the next global problem that will commence. Very less thought has been given to the question, what should be the immediate tackling process and measures against the next outbreak for Bangladesh. 
This research that why is based on the sole purpose of tackling and be as a force field against the next outbreak that might happen. For this the main objective is to build up a crisis response plan which will systematically work focusing on the purpose of tackling the next possible pandemic situation. Many researches were done dealing with the measures that should be taken (Cirrincione et al., 2020). Different preparedness and response reports have been created (Global Influenza Program, 2005) and pre-pandemic planning guidance (Centers for Disease Control and Prevention, 2007) were developed by different countries. Different strategies were proposed to prevent the future pandemics (Daszak et al., 2020) and models were also proposed for epidemic preparedness and management (Al Takarli, 2020). Although in Bangladesh much deep exploring has not yet been done in the case of tackling future outbreaks like this. Few was done regarding combating the COVID-19 in Bangladesh (Moin et al., 2020). Strategic assessment is its administration for sustainability (Shammi et al., 2020). But a fixed policy guideline and a clear measure against this was not seen.

Therefore, this article focuses on building up a fixed crisis response team with its necessary policy frameworks which will be able to tackle the future pandemic situations that might rise in the near future. The working process was not free of any limitations. All of the research is based on secondary data source and papers. No indepth surveys were possible to make due to the pandemic situation prevailing.

\section{STUDY AREA}

Bangladesh is a nation of 161 million individuals that is situated directly at the core of the Ganges-BrahmaputraDelta in South Asia. The country has stepped forward as of late regarding human turn of events. Bangladesh has left the positions of the world's least developed nations, however stays perhaps the most unfortunate country in South Asia (Etzold and Mallick, 2015). Bangladesh has been encountering an exceptionally quick movement of urbanization during the most recent forty years or thereabouts. Official insights show that the metropolitan populace (which means level of the populace living in metropolitan territories) has expanded from around 9 percent to $32 \%$ during this period. Nonetheless, as per the Agglomeration Index, an elective proportion of metropolitan focus, the portion of Bangladesh's populace living in zones with metropolitan qualities in 2010 was 45.7\%. This recommends there exists impressive concealed urbanization in Bangladesh (Peter and Roberts, 2016). It is assessed that well in front of 2050 in excess of $50 \%$ populace will be living in territories having metropolitan attributes. It implies around 120 million individuals will be living in metropolitan zones

From the data as received by WHO from national authorities, as of 10 am CEST 13 September 2020 number of COVID-19 cases confirmed are 28,637,952 and total number of deaths are 917,417. Among the continents USA had the highest confirmed number of cases which is 14,699,174 followed by South-East Asia 5,377,062 and the rest are Europe with 4,796,426 cases, Eastern Mediterranean with 2,101,676, and Western Pacific with 546,552 and Africa with 116,321 confirmed cases. In recent times the infected rate in the South- East Asia has increased rapidly. The death cases of the above regions are USA with 508,705 cases, South-East Asia with 92,391 cases, Europe with 225,494 cases, Eastern Mediterranean with 55,012 cases, Western Pacific with 11,886 cases and Africa with 23,916 cases (World Health Organization, 2020). As it is rapidly increasing in the South-East Asian region Bangladesh is also facing a huge amount of heat in regards of this disease. Because of the dense concentration of economic activities, population, physical location and rapid urbanization it has posed huge difficulties in SDG progress in the Asia-Pacific region. As of 14 September, 2020, total tested persons were 1,742,696 confirmed cases were 339,332, recovered from it 243,155 and total death count was 4,759. During this time $62.7 \%$ reported cases were from Dhaka division, $13.8 \%$ from Chattogram, Khulna 6.3\%, Rajshahi $5.8 \%$, Sylhet and Rangpur 3.5\%, Barishal 2.5\% and lowest was in Mymensingh division which was $1.9 \%$. Among the reported deaths $48.3 \%$ were from Dhaka division, 21.5\% from Chattogram, Khulna 8.4\%, Rajshahi $6.7 \%$, Rangpur $4.7 \%$, Sylhet 4.5\%, Barishal 3.9\% and Mymensingh with 2.1\% (World Health Organization, 2020).

This research narrowly defined with the country boundary to visualize the actual scenario in the pandemic situation. The policy measures will be based on the scenario of Bangladesh and all its analysis and interpretations will be based on the physical location, characteristics and attributes of Bangladesh. Here Figure 1 is provided below showing the present COVID-19 cases spread along all the divisions. The data was retrieved from WHO dashboard of 14 September 2020

\section{METHODOLOGY}

The article is mainly based on secondary data source and works of different researchers. First of all, different papers were studied from where the present COVID-19 scenario across the world was studied and the scenario was presented in front. It can be preferred as content based meta-analysis where patterns and structures of different studies were examined systematically convenient to the study area. Steps and measures taken by other countries both during the pandemic and also the future steps if taken have been studied. This is mainly a Meta- 
Analysis where a mixed approach has been adopted. Here, findings, assessment and insights of other authors have been undertaken and based on these analysis new feasible policies and an efficient framework has been proposed. Showing the situation of Bangladesh amidst of this a policy framework have been put up front based on the measurements taken in other articles. For analysis purpose graphs and charts from secondary data sources like WHO, websites of different ministries of Bangladesh, United Nation, Zabala, world meter, BBS report different annual reports of international organizations and several news reports of dailies and weeklies such as The Daily Star, The Financial Express, The Business Standard etc. were taken for backing up the policies given.

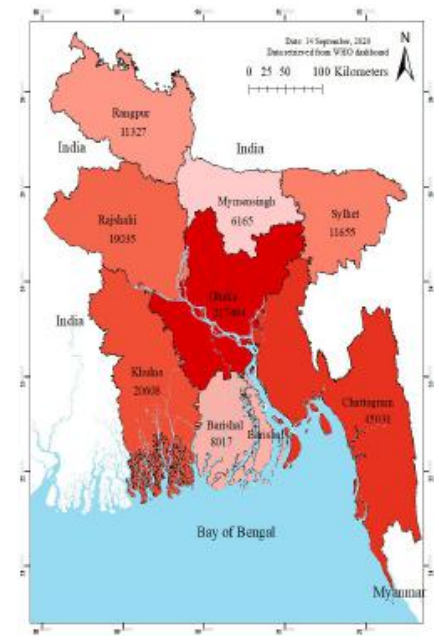

Figure 1: COVID-19 confirmed cases across Bangladesh

\section{ANALYSIS AND INTERPRETATION}

\subsection{Crisis in Educational wing}

The buzzword 'Corona Virus' has stretched out many obstacles to the world's century-ancient systems, including economic field, people's lifestyles, health regulation, educational discipline, trade and businesses process, industrial method and so on. The influence of the virus is so enormous that it has led to the closures of many countries worldwide. Therefore, the global education system is also being affected. According to UNICEF monitoring, 129 countries across the world ensuring national closures, which also means that about $63.3 \%$ of the total students enrolled in the world are impacted by such closures (Ramij and Sultana, 2020). AHM Mustafa Kamal the Finance minister assured that Covid-19 has basically caused a pause in the customary scholarly educational programs of around 40.0 million understudies all over the country. (Uddin , 2020). By the reports of the Education Ministry, Bangladesh has nearly 10.75 million primary level students (grades one to eight), almost 10.50 million secondary and higher secondary level students (grades nine to 12). The lion's share of students is from country regions, which make up $80 \%$ of Muslim-majority, to a great extent agrarian Bangladesh, and approximately one quarter are categorized in the destitute range (World Food Programme, 2020). In Bangladesh, 36.79 million students from pre-primary to upper secondary level and 3.15 million students enrolled in tertiary education are facing disruption in education because of the closures of educational institutions (Ramij and Sultana, 2020). Four million understudies of tertiary level education in Bangladesh in over 5,000 institutions counting public and private universities, subsidiary colleges, and proficient institutions are in shutdown, which might proceed until the circumstance does not make strides (Ahmed, 2020). Current COVID-19 pandemic circumstance, E-Learning or distance learning has picked up priority within the education branch; media, like Zoom, a video communication framework, has picked up tremendous notoriety amid these restriction days (Bhuiyan, 2020). For regarding of online learning availability of devices like as computer or mobile phone and at the same time internet connection are the basic equipment for online education. It was expected that the number of dropouts would rise to 30 per cent once more as guardians ended up jobless or are confronting genuine financial emergency for the amplified time of holiday (Kamol, 2020). BioTED, a novel training and research initiative, conducted a survey of 42 private and public universities and found 23 percent of students were in favor of online courses in this circumstance, whereas the remaining $77 \%$ were against the proposition. Just $55.3 \%$ of students have the affordability to a portable workstation, Computer or tablet for online course participation. It uncovers that $44.7 \%$ of students are incapable to go to online classes since of a need of coordination. Web access is the foremost critical aspect for online classes, and studies found that $55 \%$ of students are not empowered by adequate web associations to seek after online education. They too unveiled that 
$40 \%$ of students as of now go to online classes, most of them from private universities (70\%) (DU Correspondent, 2020).

Table 1: Data matrix showing the information of the adopted researches is given below:

\begin{tabular}{|c|c|c|c|c|c|}
\hline Data type & Title & Author & Source & $\begin{array}{c}\text { Publicati } \\
\text { on year }\end{array}$ & Analysis process \\
\hline Secondary & $\begin{array}{l}\text { COVID-19 Pandemic: } \\
\text { Prevention and protection } \\
\text { measures to be adopted at } \\
\text { the workplace }\end{array}$ & $\begin{array}{l}\text { L. Cirrincione; } \\
\text { F. Plescia; } \\
\text { C. Ledda; } \\
\text { V. Rapisarda; } \\
\text { D. Martorana; } \\
\text { R. E. Moldovan; } \\
\text { K. Theodoridou } \\
\text { and E. Cannizzaro }\end{array}$ & $\begin{array}{l}\text { Sustainabilit } \\
\text { y-MDPI }\end{array}$ & 2020 & $\begin{array}{l}\text { Searched and analyzed targeted } \\
\text { evidence-based guidelines issued in } \\
\text { various countries affected by this } \\
\text { epidemic up to date. }\end{array}$ \\
\hline Secondary & $\begin{array}{l}\text { A strategy to prevent } \\
\text { future epidemics similar to } \\
\text { the } 2019 \text {-nCoV outbreak }\end{array}$ & $\begin{array}{l}\text { P. Daszak; } \\
\text { Kevin J. Olival; } \\
\text { Hongying Li }\end{array}$ & $\begin{array}{l}\text { Biosafety } \\
\text { and Health }\end{array}$ & 2020 & $\begin{array}{l}\text { Close monitoring of deadly pathogen } \\
\text { evolution and reducing the risk of } \\
\text { people having contact with the wild life }\end{array}$ \\
\hline Secondary & $\begin{array}{l}\text { China's Response to the } \\
\text { COVID-19 } \\
\text { Outbreak: A Model for } \\
\text { Epidemic } \\
\text { Preparedness and } \\
\text { Management }\end{array}$ & $\begin{array}{l}\text { Nourah S. Al } \\
\text { Takarli }\end{array}$ & $\begin{array}{l}\text { Dubai } \\
\text { Medical } \\
\text { Journal }\end{array}$ & 2020 & $\begin{array}{l}\text { Epidemic preparedness management } \\
\text { strategies comparing CDC and WHO's } \\
\text { frameworks and guidelines }\end{array}$ \\
\hline Secondary & $\begin{array}{l}\text { Combating COVID-19 } \\
\text { Pandemic in Bangladesh: } \\
\text { A Memorandum from } \\
\text { Developing Country }\end{array}$ & $\begin{array}{l}\text { A. T. Moin; M. N. } \\
\text { Sakib; Y. Araf; } \\
\text { B. Sarkar; } \\
\text { Md. A. Ullah }\end{array}$ & $\begin{array}{c}\text { Preprints } \\
\text { (www.prepri } \\
\text { nts.org)| } \\
\text { NOT PEER- } \\
\text { REVIEWED }\end{array}$ & 2020 & $\begin{array}{l}\text { Presented different activities and } \\
\text { encountering measures taken by } \\
\text { Bangladesh against COVID-19 }\end{array}$ \\
\hline Secondary & $\begin{array}{l}\text { Strategic assessment of } \\
\text { COVID-19 pandemic in } \\
\text { Bangladesh: comparative } \\
\text { lockdown scenario analysis, } \\
\text { public perception, } \\
\text { and management for } \\
\text { sustainability }\end{array}$ & $\begin{array}{l}\text { M. Shammi; Md. } \\
\text { Bodrud-Doza; A. } \\
\text { R. M. T. Islam; } \\
\text { M. M. Rahman }\end{array}$ & $\begin{array}{l}\text { Environment, } \\
\text { Development } \\
\text { and } \\
\text { Sustainabilit } \\
\text { y }\end{array}$ & 2020 & $\begin{array}{l}\text { Descriptive statistics (e.g. frequencies, } \\
\text { percentages, and Student T test) used. } \\
\text { set of statistical tools such as principal } \\
\text { component analysis (PCA), hierarchical } \\
\text { cluster analysis (HCA), Pearson's } \\
\text { correlation coefficient(PCC), multiple } \\
\text { regression analysis (MRA), and } \\
\text { classical test theory (CTT) were used in } \\
\text { analysis }\end{array}$ \\
\hline Secondary & $\begin{array}{l}\text { Pandemic Influenza } \\
\text { Preparedness and response }\end{array}$ & WHO & - & 2005 & $\begin{array}{l}\text { Roles played by WHO and government } \\
\text { in National Preparedness and Response }\end{array}$ \\
\hline Secondary & $\begin{array}{l}\text { Interim Pre-Pandemic } \\
\text { Planning Guidance: } \\
\text { Community Strategy for } \\
\text { Pandemic Influenza } \\
\text { Mitigation in the US- }\end{array}$ & $\mathrm{CDC}$ & - & 2007 & $\begin{array}{l}\text { Early, Targeted, Layered Use of No } \\
\text { Pharmaceutical Interventions }\end{array}$ \\
\hline
\end{tabular}

Table 2: A survey result of 409 Students from Bachelor of Business Private Universities are given below

\begin{tabular}{|c|c|c|c|c|c|}
\hline Section & Category & $\begin{array}{c}\text { Outcome of } \\
\%\end{array}$ & Section & Category & $\begin{array}{c}\text { Outcome of } \\
\%\end{array}$ \\
\hline \multirow{5}{*}{$\begin{array}{c}\text { Attendance } \\
(\%)\end{array}$} & $90-100$ & 7 & \multirow{4}{*}{ Status of living } & Dhaka metro & 29 \\
\hline & $70-80$ & 14 & & City corporation & 15 \\
\hline & $50-60$ & 15 & & Municipality & 14 \\
\hline & 40 & 17 & & Union & 28 \\
\hline & Below 30 & 47 & \multirow{4}{*}{$\begin{array}{l}\text { Internet speed } \\
\quad(\mathrm{mbps})\end{array}$} & $>10$ & 1 \\
\hline \multirow{2}{*}{$\begin{array}{l}\text { Technical } \\
\text { support }\end{array}$} & Received & 16 & & $5-9$ & 6 \\
\hline & Not received & 84 & & $1-4$ & 29 \\
\hline \multirow[t]{4}{*}{ Device used } & Laptop/Desktop & 15 & & $<1$ & 63 \\
\hline & Tab/I pad & 1 & \multirow{3}{*}{ Software used } & Google classroom & 58 \\
\hline & Smartphone & 82 & & Zoom & 30 \\
\hline & Others & 2 & & Skype & 3 \\
\hline \multirow[t]{5}{*}{ Internet type } & Broadband & 27 & \multirow{3}{*}{ Financial crisis } & Facebook/messenger & 9 \\
\hline & Public Wi-Fi & 5 & & Yes & 92 \\
\hline & Others & 1 & & No & 8 \\
\hline & \multirow[t]{2}{*}{ Mobile data } & 67 & \multirow{2}{*}{$\begin{array}{l}\text { Remark (cost of } \\
\text { online class) }\end{array}$} & Expensive & 58 \\
\hline & & & & Not expensive & 42 \\
\hline
\end{tabular}


The table contains the surveyed results of the study. Mainly it gave emphasis on the attendance outcome of student, the technical support available, the type of device used by the students, what type of internet is used, status of living, speed of the prevailing internet, software used to get access to online class, whether the expense for online class is bearable or not and whether there is any financial crisis or not (Ramij and Sultana, 2020).

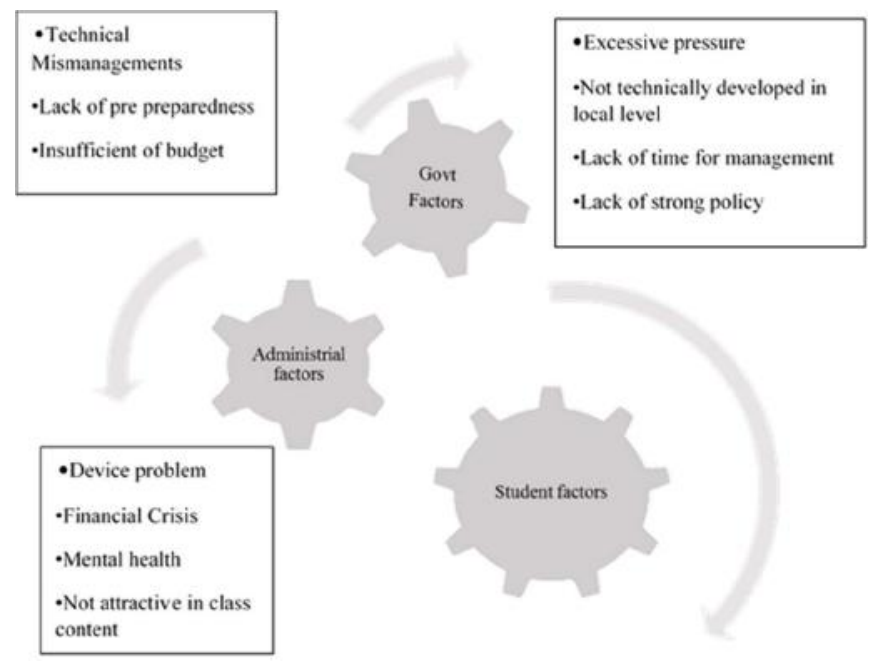

Figure 2: An overlook of all factors that works beyond the crisis of E-learning system
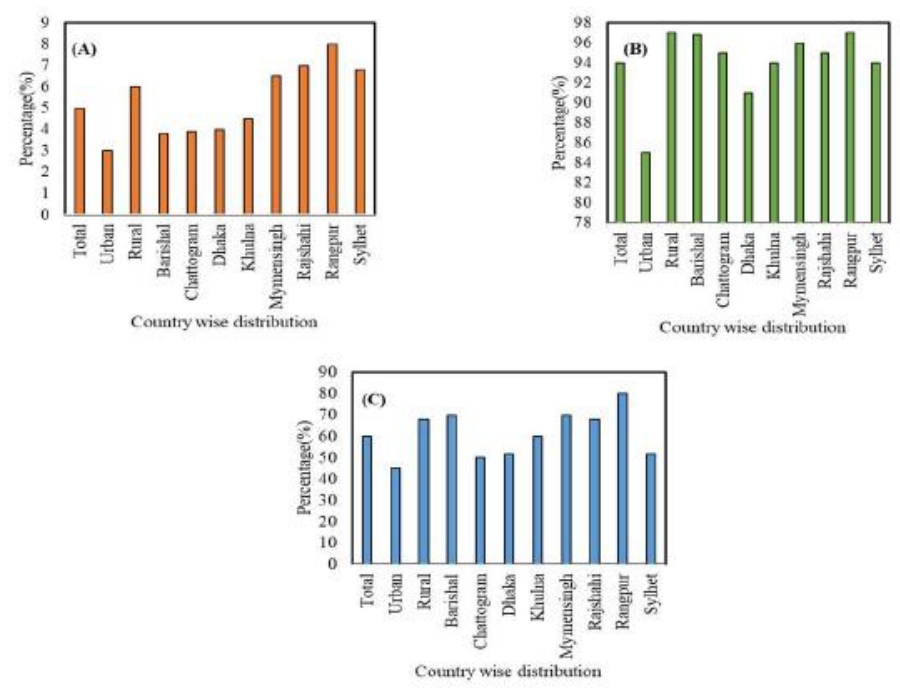

Figure 2: The background scenario of the Device and internet connection in Bangladesh, (a) HH with a single mobile, (b) without a single mobile, (c) without internet access, Source: (MICS, 2020)

A most recent survey of 2038 student in 45 higher education institutions found that one third of understudies in Bangladesh did not want to take part in online learning activities. It moreover detailed that $55 \%$ of the students were not associated with appropriate web connections and $44.7 \%$ did not have access to a savvy gadget (i.e., laptop, PC, tablet, etc.) to engage viably in online learning (Islam et al., 2020). In 2016, Bangladesh went through around $1.5 \%$ of GDP on education. Particularly in terms of adding up to tax income, the nation went through as it were $17.7 \%$ on education (Uddin , 2020). Suicide pact term is introduced for the online learning issue. The term "suicide pact" more often than not alludes to concurrent suicides of two or more people of near relationship (Mamun et al., 2020). On 11 June, 2020 in Bogura mother (aged 47 years) and son private university student, (aged 22 years) committed suicide together by ingesting noxious gas tablets due to the COVID-19-Related Online Learning Issues (Mamun et al., 2020). Concurring to the most recent Household Income Expenditure Survey (HIES) guarantee that - some time recently the plague circumstance, $23.90 \%$ (or 8.4 million) of the students' families were underneath the standard destitution line. As the emergency stretches,

expecting the time of three months' lockdown since 25 March, hence a $25.0 \%$ drop in yearly per capita salary, SANEM report that as many as $43.90 \%$ of the students' families might drop underneath the poverty line (for 
primary: $51.70 \%$, secondary: $42.40 \%$; SSC/HSC: $30.20 \%$; and university: $19.0 \%$ ).Further as many as 7.70 million supplementary students' families dropping underneath the destitution line amid this emergency, bringing the overall student population below the poverty line to 16 million (Uddin , 2020). According to BANBEIS out of the 16.0 million understudies from destitute families - numerous might never come to schools ever once more. Note well-meaning, the dropout rate in Bangladesh is still too high for secondary $(37.60 \%)$ and postsecondary education (19.60\%) (Uddin , 2020).
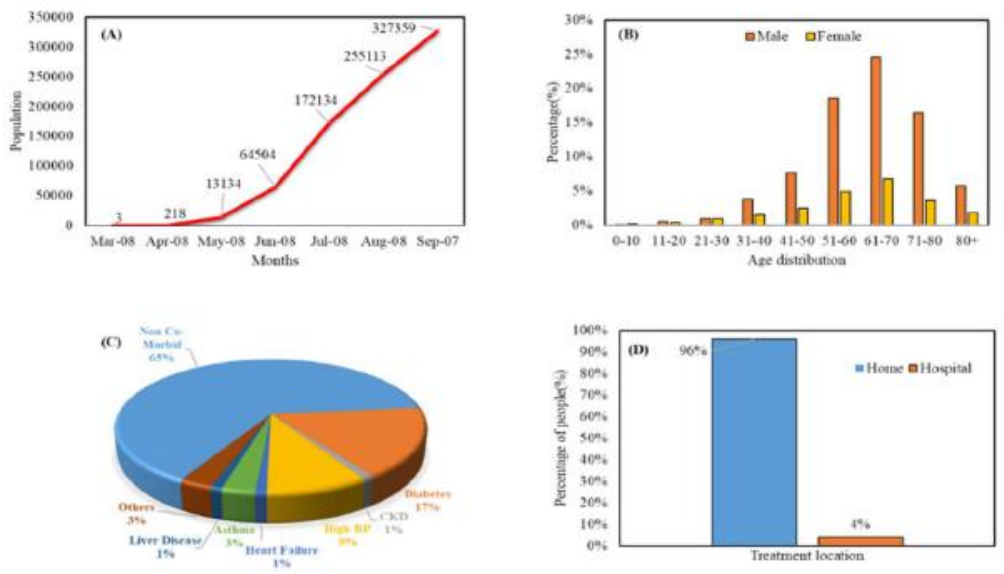

Figure 3: Health sector effect, (a) Rise in covid-19 cases since March, (b) Death patient's status, 15 July-5 September, (c) Proportion of morbidity and co-morbidity, (d) Proportion of treatment location Source: (Directorate General of Health Services, Ministry of Health, ICT Division, 2020)

\subsection{Effect in Health sector}

In Figure 4a, the unexpectedly rapid increase of confirmed covid-19 cases is represented from March 08 till September 7. The virus is badly spread out in day by day by community transmission. In Figure $4 \mathrm{~b}$, it shows that in every age classes of people, the man is the mainly victim person in death cases than women perception. Since man is forced to go out to work or may be due to some hormonal factors, here the probability has to be affected by the virus. The context of Figure $4 \mathrm{c}$ the non-comorbidity part response is $65 \%$. In morbidity sector, here the diabetes disease patients are more response that is $17 \%$ among the liver disease, asthma, heart failure, CKD (Chronic Kidney Disease), high BP (Blood Pressure) and others diseases. In the scenario of treatment location, the high portion of people is responded to home treatment in the mid time of epidemic situation. Only 4\% people are in the hospital for treatment that represents in Figure 4d. It means that lack of accommodation the medical services cannot face the huge patient for services. The most effect caused in this situation is in the health sector. Massive effect was posed on both physical and mental health. The reasons for that are given below:

Table 3: Among the respondent's number of 1427 in the concern of mental health

\begin{tabular}{ccc}
\hline Type of Symptoms & The order of category value & Average \% of suffered \\
\hline Stress symptoms & Mild $(28.0 \%)$ and moderate & $(22.0 \%)$ \\
Symptoms of anxiety & $\begin{array}{c}11.6 \% \text { had moderate anxiety } \\
\text { indications, and } 11.6 \% \text { had } \\
\text { extraordinary anxiety indications } \\
\text { Mild }(14.5 \%), \text { moderate }(21.2 \%), \\
\text { and severe }(13.2 \%) \text { levels }\end{array}$ & 33.7 \\
Depressive symptoms & & 57.9 \\
\hline
\end{tabular}

Source: (Banna et al., 2020)

\subsubsection{Mental Health}

Mental wellbeing amid the COVID-19 pandemic is related with sex, financial status, occupation, having COVID-19-like side effects, discernments of COVID-19 impacts, interpersonal clashes, social media utilization and social bolster (Mowbray, 2020). The novel coronavirus-2019 (COVID-19) pandemic has had an expansive impact on mental wellbeing all inclusively and has driven people dreading COVID-19 contamination alongside conditions such anxiety, misery, trauma, and stress (Ahorsu et al., 2020). The report moreover found out higher levels of stress were expressively connected with females $(70.9 \%)$, month to month wage $>40,000$ BDT $(63.8 \%)$, and unemployment $(71.9 \%)$. The predominance of anxiety indications was essentially higher among 
females ( $45.6 \%$ ), those $\geq 40$ years of age ( $44.0 \%$ ), those with low education (secondary; $87.5 \%$ ), and housewives $(68.2 \%)$. Higher rates of depressive side effects were related with females $(64.3 \%), \leq 23$ years of age $(62.8 \%)$, and the unemployed (77\%) (Banna et al., 2020). The result of the impact of COVID-19 episode in Bangladesh, over one third (35.5\%) accepted pandemic had a medium impact on mental wellbeing. Over half (59.8\%) accepted that COVID-19 disturbed the wellbeing care framework. A lion's share $(81 \%)$ thought that the most exceedingly bad is however to come. A larger part (77.2\%) too accepted that the pandemic would adversely affect the division of work, wage, or education (Banna et al., 2020)

\subsubsection{Health care profession crisis}

The COVID-19 emergency has battling healthcare professionals (HCPs) around the world into an unparalleled circumstance coming about in life-threatening weight which influences people mentally (Greenberg et al., 2020). There are a numerous number of clarifications that have contributed to the mental burden of HCPs reasons counting: (i) need of fitting and adequate sum of quality personal protective equipment, (ii) being uncovered to a possibly deadly infection, (iii) being a carrier of the infection and stressing that they will sully their families, (iv) not having incite access to testing in case they create indications and an associated fear of engendering contamination within the work environment, (v) vulnerability as to whether their employer will back and/or watch out of their individual and family needs in case they progress contamination, (vi) need of access to childcare amid expanded work hours and school closures, (vii) lack of bolster for other individual and family needs as work hours and requests increment (nourishment, hydration, lodging, transportation), (viii) stressing whether they can give competent restorative care (Mamun et al., 2020). A startling occurrence has happened on 20 May, a 40-year-old lady named Sojni was dead hanging within the women's ward lavatory hospital in Hili, Dinajpur. Onlookers at the hospital said that once the patient was admitted, medical caretakers and doctors denied for any kind of treatment because of possible contamination of COVID-19 and did not want to get contaminated themselves. The people also claimed that the hospital staff too denied assisting the woman (Mamun et al., 2020). Effect of health sector is clearly seen in the maps given above showing the number of ICU's Figure 5a, COVID-19 deaths Figure 5b, testing laboratory locations Figure 5d, recovery cases Figure 5e and hospitalized patient count Figure $5 \mathrm{~g}$.

\subsection{Economic Crisis}

The worldwide COVID-19 pandemic is formerly making a lavish ground for fortifying Raymond Pearl's logic of seeing the human in a financial holder (Jamal, 2020). According to a forecast of the World Food Program, up to 265 million individuals in low- and middle-income nations will confront intense food uncertainty by the conclusion of 2020 due to the Covid-19 financial impacts (Chowdhury, 2020). COVID-19 presents not as it were a wellbeing emergency, but moreover confronts a food emergency for Dhaka's poorest (Taylor, 2020). In the meantime, both developing and less developed nations are apparently encountering more extreme emergencies than developed nations, with numerous little and medium-sized businesses being aggravated and even bankrupt (Fernandes, 2020). Economic collapse, unemployment, and destitution are unequivocally interconnected with extreme mental co-morbidities like as self-destructive behaviors (Goldman-Melloret al., 2010).

Concurring to the South Asian Network on Economic Modeling (SANEM), Bangladesh's poverty rate may duple to $40.9 \%$ from that earlier to the graduation of the pandemic among the 100.22 million individuals at in stature chance of financial and wellbeing vulnerabilities, 53.64 million are greatly poor. These sorts of individuals gain less than 160 Taka $(€ 1.7, \$ 1.9)$ a day (Ahmed, 2020). The Prime Minister at first articulated a crisis stimulus package of $\$ 600$ million (equivalent to $0.2 \%$ of GDP) on 25 March, which on 4 April was boosted altogether to $\$ 8.5$ billion (proportionate to $2.5 \%$ of GDP) (Islam and Divadkar, 2020). In this emergency, the government may consider a budget error of up to $8-10 \%$ as divergent to the $4-5 \%$ budget shortage in ordinary times (Raihan, 2020). The crisis-related borrowing will progress the open debt-to-GDP proportion to around 41 percent of GDP over the coming years, from 36 percent at the conclusion of 2019 (Gudmundsson, 2020). In the context of garments and textile industry, bookkeeping for $12 \%$ of net domestic products and $84 \%$ of exports, is all of a sudden in drop of emergency. In April, for example, garment exchanges produced to just $\$ 380$ million, against $\$ 2.26$ billion a year than the previous (Pesek, 2020). The readymade garments (RMG) are concerned very much within the monetary year 2019-2020, the profit from RMG exports dropped by $18.12 \%$ from the past year (Raihan, 2020). Study conducted in May by Bangladesh Institute of Development Studies (BIDS) found an enormous 16.4 million people sliding under the poverty line due to the epidemic (Jamal, 2020). The nation is anticipated to lose roughly $\$ 3$ billion in GDP (i.e., 1.10\% total decrease) and there will be work misfortunes for around nine million individuals in this circumstance which is also getting more awful day by day (Bhuiyan et al., 2020). 
The economic crisis is easily visible from the above maps showing migration prone districts since major amount of people of the city lost their jobs Figure 5c, Women headed household percentage Figure 5f, Extreme poor household locations as the unemployment increased Figure 5h, count of small income source such as rickshaw pullers and tea stall vendors as their work is on the verge of getting hampered due to this crisis Figure $5 \mathrm{i}$.

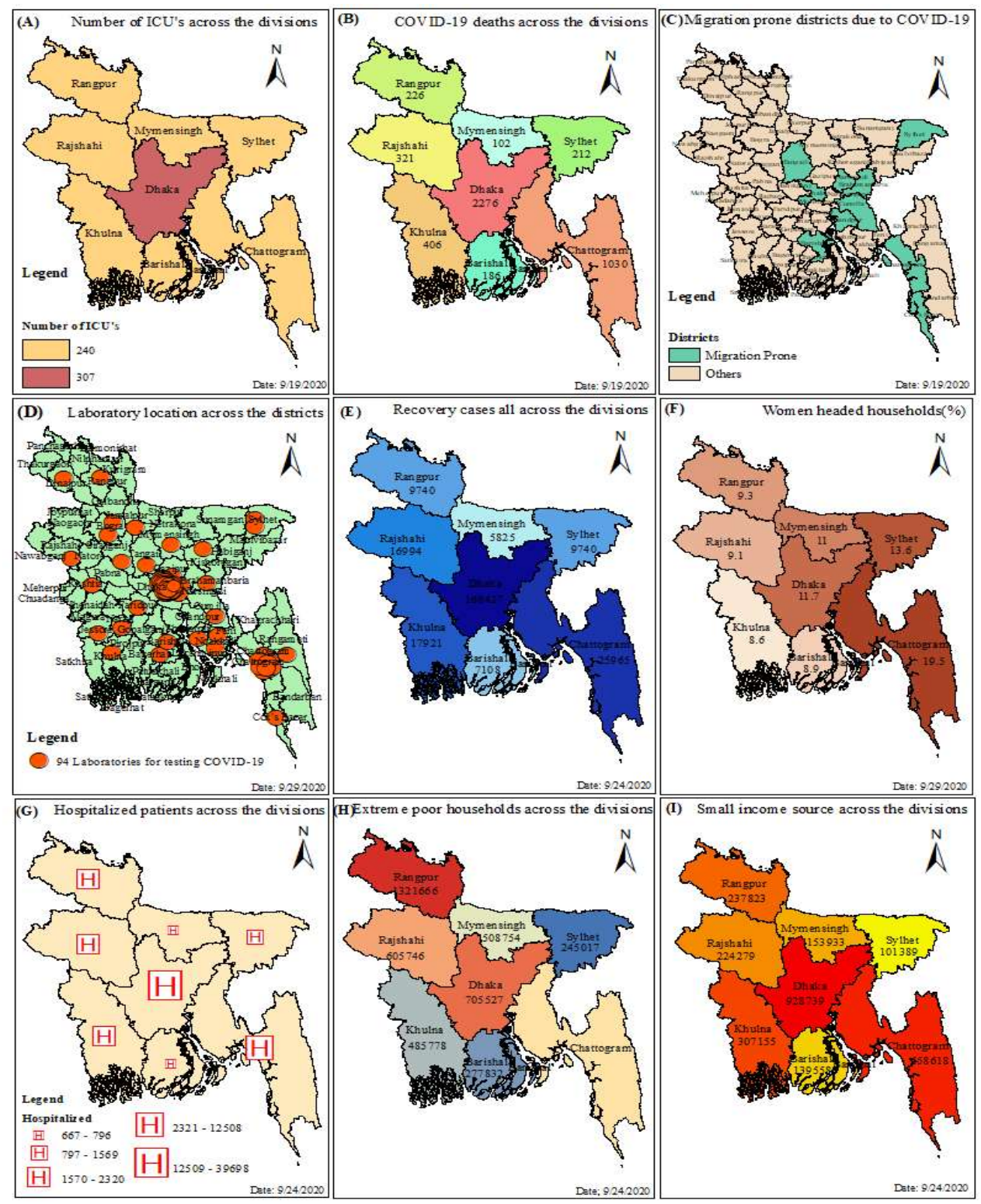

Figure 4: Situation of Health and economic sector, (a) ICU count, (b) Deaths, (c) Migration prone districts, (d) Laboratory location, (e) Recovery cases, (f) Women headed households, (g) Hospitalized patients (h) Extreme poor households, (i) Small income source

\subsection{Lockdown Scenario}

One such member of a life-threatening poor family, Maleka Begum of Shahagola union of Atrai in Naogaon district, whose spouse used to work at least 90 days amid the Boro gathering period in this time of other years, but this year managing work was possible for 22 days due to the lockdown (Chowdhury, 2020). A field-based advancement laborer affianced in job projects for the extreme destitute in Kurigram, agricultural every day stipend laborer more often than not wins around Tk. 10,000 amid this period by working in several places of the country. This year, this same day laborer might not gain more than Tk. 2,000 to Tk. 3,000 due to movement confinements in lockdown period (Chowdhury, 2020). Another story is remarked Mohammad Nurunnabi (39) who grows vegetables in the estate garden Banani TNT Colony. 


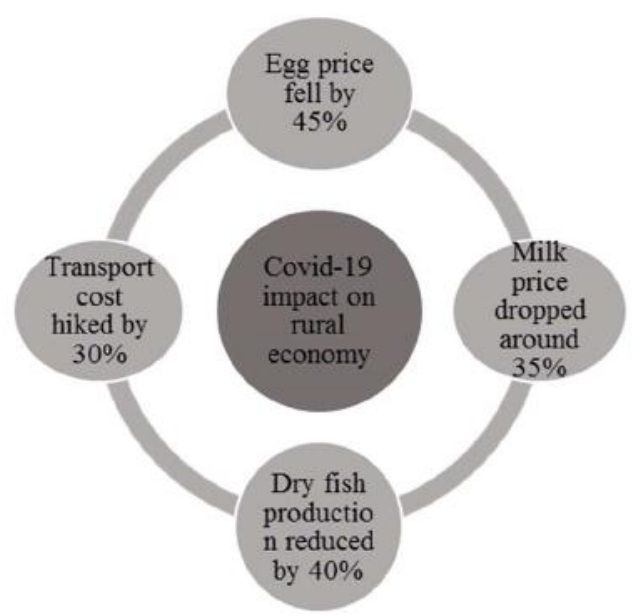

Figure 5: COVID-19 impact on rural economy Source: The Business Standard

Table 4: An overview of suicidal case study during the period Lockdown

\begin{tabular}{|c|c|c|c|c|}
\hline $\begin{array}{l}\text { Case } \\
\text { study }\end{array}$ & Date & Place & Profile of felo-de-se & Reason of incident \\
\hline 01 & 6 April & Jhenaidah & An adult man(aged30years) & Due to the weight of unpaid obligations \\
\hline 02 & 10 April & Sirajgonj & $\begin{array}{l}\text { a female juvenile } \\
\text { (aged } 10 \text { years) }\end{array}$ & $\begin{array}{c}\text { Was reproached by her father for inquiring } \\
\text { for food }\end{array}$ \\
\hline 03 & 12 April & Coxs bazar & a woman (aged 35 years) & Her spouse lost his work since lockdown \\
\hline 04 & 13 April & Natore & $\begin{array}{l}\text { a young grown-up man } \\
\text { (aged } 27 \text { years) }\end{array}$ & $\begin{array}{c}\text { He became unexpectedly unemployed } \\
\text { during lockdown }\end{array}$ \\
\hline 05 & 14 April & Dhamrai & a woman & Garment factory shutdown \\
\hline 06 & 16 April & Chattogram & an adult man (aged 30 years) & $\begin{array}{l}\text { During the lockdown he was unable to use } \\
\text { his vehicle }\end{array}$ \\
\hline 07 & 24 April & Keshapur & $\begin{array}{l}\text { a poverty-stricken husband } \\
\text { (aged } 30 \text { years) }\end{array}$ & Due to excessive debts \\
\hline 08 & 24 April & Keshapur & wife (aged 24 years) & Lockdown-related economic distress. \\
\hline
\end{tabular}

It was seen that sudden taking off from garment factory work happened due to the lockdown. Within the Korail Bosti, a casual settlement of over 100,000 residents living within the city center, 20 venturesome occupants have developed little vegetable gardens on the banks of the adjoining lake. With occupations rare, counting on the growing crops was imperative and offering produce to neighbors at costs well underneath the genuine showcase rate (Taylor, 2020). However, as COVID-19 pandemic hit the nation inside 2 weeks poverty rate in Bangladesh rose to $40.9 \%$ as $25 \%$ of family salaries fell is affecting on financial sustainability and well-being, which may actuate mental mediators, such as pity, stress, fear, outrage, irritation, disappointment, guilt, helplessness, depression, and anxiety related to financial subsidence, unemployment, and poverty are emphatically related with extreme mental co-morbidities such as suicidal behaviors (Ahorsu et al., 2020). In 2020, the annual percentage of GDP growth rate is decreased (2\%) within unexpected rate compare with the past experience. In the initial period of pandemic, the Remittance inflow was already 1290 (In million USD) decreased. Its act a great negative impact of economic sector that is not possible to overcome in easily to develop the economic aspect. In the period of lockdown, the schedule of airline was hampered. A few numbers of flights were active in that crisis.

In the perspective of private credit growth percentage, the decreased percentage was 9.1 in February. In the concern of risk of losing employment (In millions), the RMG sector is in the danger situation. Dairy, poultry, transportation, tourism sector will be also faced risk of losing employment. Its play threaten role for the industrial sector in economy. The lockdown effect was also affecting the hotel sector. The occupancy rate of hotel was decreased in that period. Overall, the all dimension of economic sector is badly damaged.

\subsection{General Public perception}

Different opinioned surveys have already been conducted regarding public's perceptions on COVID-19. One such study result has been presented in the Table 5 


\section{POLICY}

For setting up the proposals some literature reviews were made and several research articles were reviewed (Baker et al., 2020; Berger et al., 2020; Kuckertz et al., 2020; Liu et al., 2020; Prem et al., 2020). Some literature reviews have been made on the basis of the reviewed articles. Based on those some proposed guidelines have been given in the context of Bangladesh.
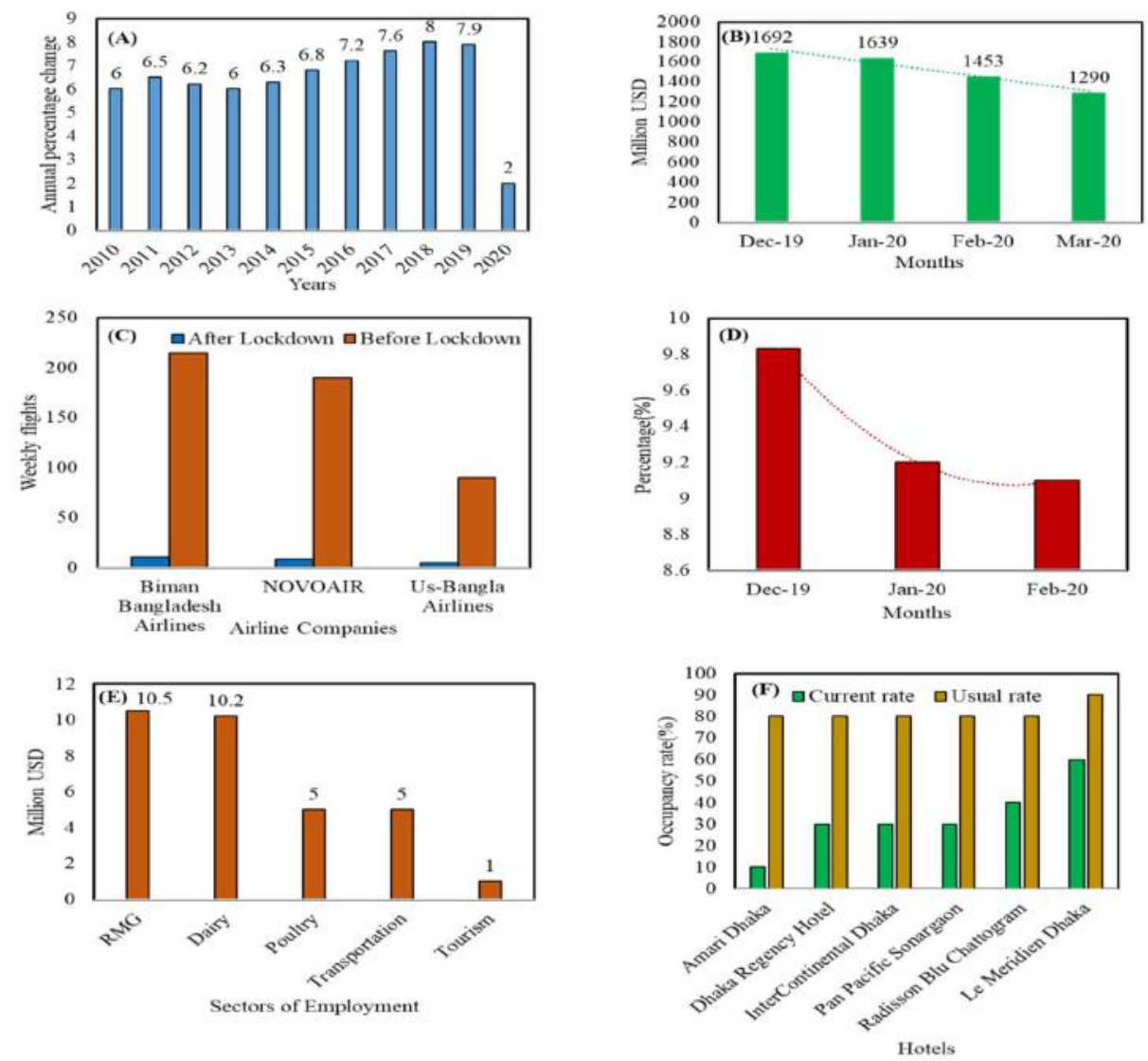

Figure 6: Effect on economy, (a) Real GDP growth annual \% change, (b) Remittance inflow (In million USD), (c) Lockdown effect (Changing in weekly flight), (d) Private credit growth \%, (e) At risk of losing employment (In millions), (f) Lockdown effect (occupancy rate of hotel), Source: (DATABD, 2020)

\subsection{Proposal for Crisis Response Management}

A crisis respond team will be buildup based on the committee given in Figure 8 . The sector will contain in total 10 parts all internally or externally related with it. A diagrammatic representation of the sector is given in Figure 9. This above figure shows a framework containing all the possible members of a crisis respondent team, their team member numbers and their activities. Mainly in the higher chief authority position there will be our honorable prime minister. Under that position there will be other concerned ministries working on how the conduction during the time of the crisis will be done. At the bottom there will be 10 people in the field coordinator sector monitoring field activities and reporting to the higher authorities. Immediate after that there will be an execution committee who will report the activities given from the field coordinators and pass it to higher authorities and execute activities according to the needs of downward and from the guidance that will come from the upper side.

The analysis of the research was mainly based on the present condition of education, economy and public health sectors. Furthermore, insights of the subsectors relating is above ones. Based on this policy implication were provided with subsidiary help from policies and proposals of other researches. And based on these why should it be implemented in Bangladesh has been discussed. Suppose in (Baker et al., 2020) utilizing transaction-level financial data the amount of household consumption during COVID-19 has been measured, (Berger et al., 2020) is based on free testing policy and employment rights like paid sick leave policies. Again in (Kuckertz et al., 2020) gave emphasis on how startup can be a rapid response in COVID-19 also, access to wider entrepreneurial ecosystem for long term measures have been discussed. Liu et al. (2020) is on the basis of mental halth services 
of China andits activities during this pandemic whereas, Prem et al. (2020) emphasizes on using synthetic location-specific contact patterns in Wuhan for identifying social mixing during this pandemic and impose some control strategies against it. All of these studies were based on certain specific sectors and specific reasoning. So, based on this the conducted research took into account all the possible sectors affected in this pandemic and imposed a blueprint of accessing the problems of these sectors not only for this pandemic but also for any future hazards. A proposed one stop committee to evaluate the functions of respondent sectors is given in Figure 8. In the committee there will exist a partnership between the administrative personnel of the government of Bangladesh and teams containing people from private sectors with NGO as well.
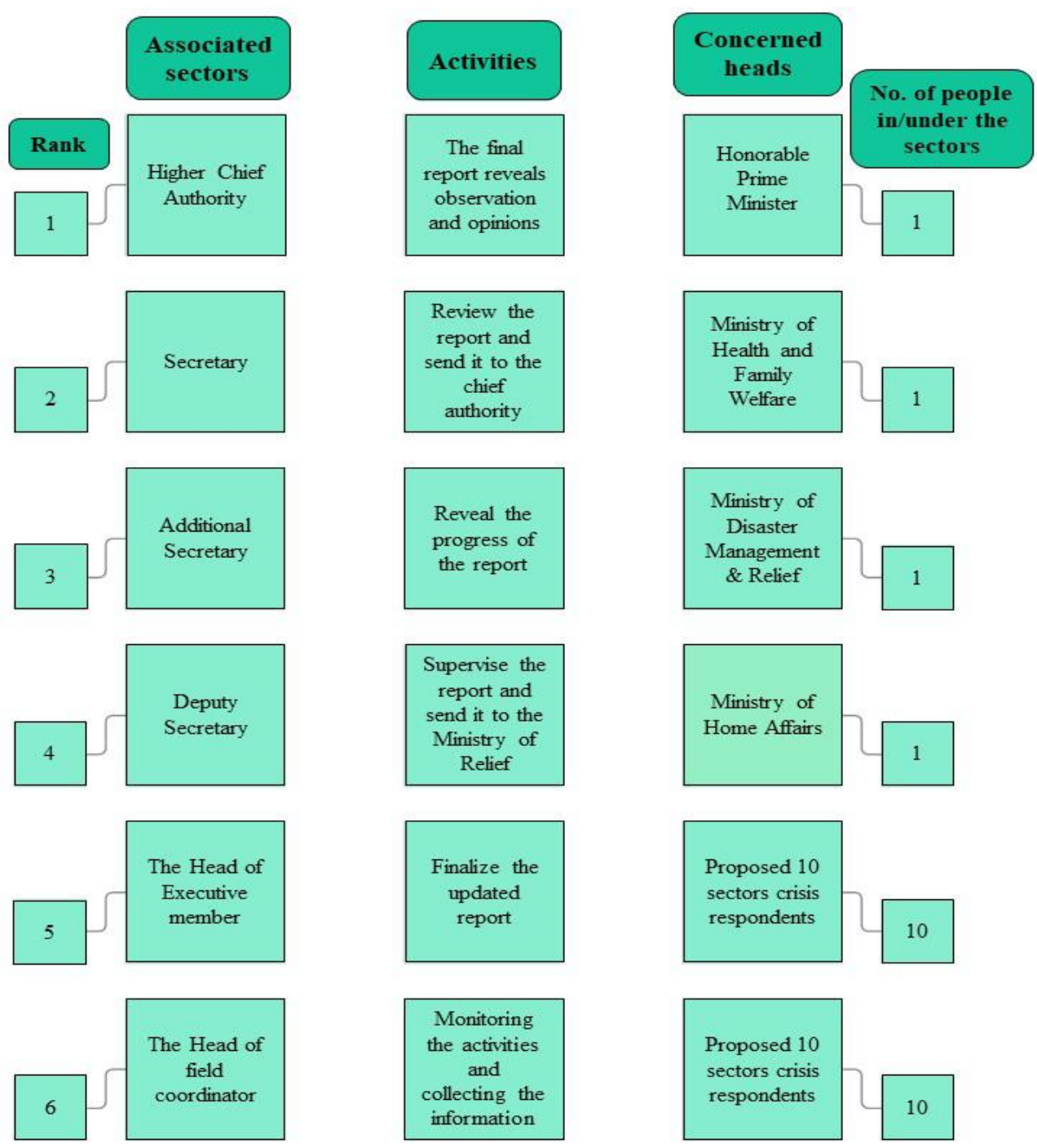

Figure 8: Proposed Committee of the Authority for Monitoring the Plan

The government of Bangladesh already has a considerable amount of plan, policy, committee, frame work both of national and local level in the sector of disaster management such as (Union Disaster Management Committee (UDMC), Inter-Ministerial Disaster Management Coordination Committee (IMDMCC), and District Disaster Management Committee (DDMC). The sole purpose of these committees is the management of emergency situation of natural disaster. But the preparedness tactics to cope up with the pandemic situation lacks in policy and strategy level. In Bangladesh, National Preparedness and Response Plan for COVID-19 was published in March (Azad, 2020). Here, no specific crisis response management sector has been declared and no plan nor any strategy is being mentioned for proper urban planning in the post covid-19 scenario. This study focuses mainly on the health sector crisis and about the management fund. 
Table 5: A perception-based questionnaire was surveyed online for Bangladeshi 1066 citizens

\begin{tabular}{|c|c|c|c|}
\hline Sector & Statement & $\begin{array}{l}\% \text { of Respondent } \\
\text { (strongly agreed) }\end{array}$ & Mean value \\
\hline \multirow{4}{*}{$\begin{array}{l}\text { Mental health } \\
\text { status }\end{array}$} & Afraid of the recent outbreak & 46.2 & $4.15 \pm 1.01$ \\
\hline & Afraid of getting infected & 32.7 & $3.89 \pm 1.08$ \\
\hline & Afraid of losing my life or my relatives & 43.6 & $4.08 \pm 1.08$ \\
\hline & Bangladesh is fragile and unable to deal & 62 & $4.36 \pm 1.01$ \\
\hline \multirow[t]{2}{*}{$\begin{array}{l}\text { Healthcare } \\
\text { system }\end{array}$} & $\begin{array}{c}\text { A huge population is a pressure to the } \\
\text { existing healthcare system } \\
\text { There is a lack of awareness of }\end{array}$ & 68 & $4.51 \pm 0.87$ \\
\hline & Basic healthcare issues & 67 & $4.55 \pm 0.776$ \\
\hline \multirow{4}{*}{$\begin{array}{l}\text { Governance } \\
\text { and political } \\
\text { perspective }\end{array}$} & $\begin{array}{c}\text { Bangladesh government cannot deal with } \\
\text { this outbreak }\end{array}$ & 18 & $2.50 \pm 1.28$ \\
\hline & $\begin{array}{l}\text { Government needs support from general } \\
\text { public to reduce the impact of COVID-19 }\end{array}$ & 68.6 & $4.56 \pm 0.77$ \\
\hline & $\begin{array}{c}\text { Developed nations are going to support } \\
\text { Bangladesh }\end{array}$ & 31.6 & $3.45 \pm 1.0$ \\
\hline & $\begin{array}{c}\text { The lockdown of regular activities was a } \\
\text { good decision }\end{array}$ & $61-65$ & $4.53 \pm 0.77$ \\
\hline \multirow{2}{*}{$\begin{array}{l}\text { Socio- } \\
\text { economic } \\
\text { aspects }\end{array}$} & $\begin{array}{c}\text { Poor people living of daily wages will be } \\
\text { severely affected" }\end{array}$ & 85.6 & $4.78 \pm 0.60$ \\
\hline & $\begin{array}{l}\text { poor people living in urban areas have to } \\
\text { leave the city }\end{array}$ & 60.5 & $4.42 \pm 0.87$ \\
\hline \multirow{3}{*}{$\begin{array}{l}\text { Emerging } \\
\text { issues }\end{array}$} & $\begin{array}{l}\text { There is a chance of community } \\
\text { transmission of COVID-19 }\end{array}$ & 56.4 & $4.39 \pm 0.82$ \\
\hline & A huge number of people will be infected & 69 & $4.208 \pm 0.93$ \\
\hline & There is a chance of severe food scarcity & 54 & $4.65 \pm 0.68$ \\
\hline
\end{tabular}

Source: (Bodrud-Dozaet al., 2020)

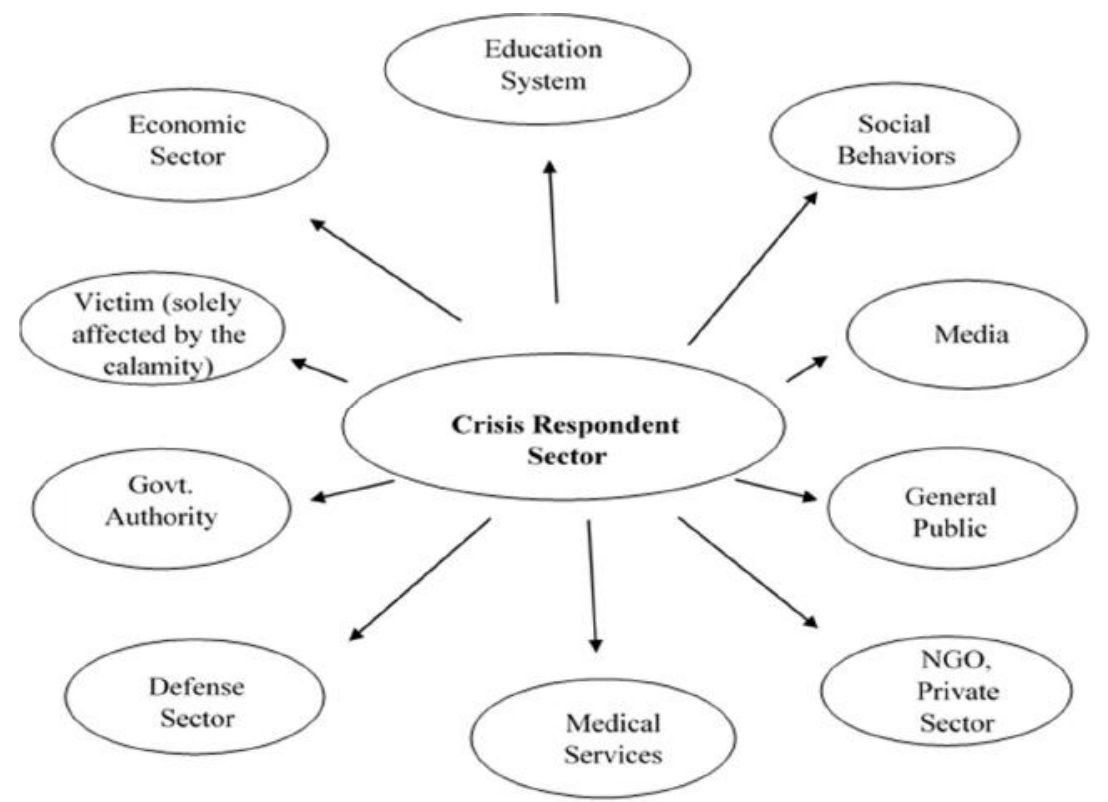

Figure 9: Response Team associates

There are other important sectors like education, economy which are deprived from National Preparedness and Response Plan for COVID-19. Again, it is only controlled by the ministry of health and family affairs. Also, this plan is not suitable for any future epidemic situation. For this reason, it is required to adopt plan, policy, and framework with strategic approach to manage the post covid-19 crisis response management. In this case, also a committee is required which is organized by not only one ministry but also others are involved. As crisis response sectors have been declared here properly, the responsibility of the government will be minimized. Furthermore, this proposal of crisis response management will be effective in any epidemic situation in the 
future. The sector will contain in total 10 parts all internally or externally related with it. A diagrammatic representation of the sector is given below:

\section{Response from the Govt. Authority:}

1. Emergency fund reform: An emergency fund is formed which will be processed by the NID no of the citizens of the country. The local authorities will help in setting up a survey which will portray only those families whose income source stopped due to the hazard. The NID cards will determine equal distribution of the fund.

2. Life insurance: The person who is at stake in the pandemic situation for giving services, a sufficient amount compensation can be given both by Govt. and private organizations employee like as (medical staff, police or defenses members) by life insurance. Taking $20 \%$ from the pension money will reduce the liability of the government a little.

3. Infrastructure Induction: A new special category infrastructure in the name of "Emergency Hospital" for the positive patient. Useless govt. building or old unused building can be used for the purpose of emergency hospital.

4. Equity monitoring: An organization can be formed in the name of "Mandatory of Equity". Its motto to control the aid in all classes and all affected and suffered areas of Bangladesh. A decentralized local committee will monitor the activities; here local manpower such as scouts, BNCC etc. will help monitoring the proper distribution of the facilities.

5. Lockdown Policy: Keeping in mind the country's economy background, of course, the lockdown policy must be adopted. At the same time, its remind that all the people must get the daily basic items in available.

6. Zero Hunger policy: In the time period of pandemic situation at the same time the fatal poverty is noticed in the context of present scenario. In this background a committee or organization like as "Ek Takar Ahar or Biddanondo foundation" can be formed to take decision and ensure the progress of the activity.

7. Research: In epidemic situation for virus, Genome sequence analysis is must for realize the adaptation of the virus. So, for this, a research institute can be established and inspire in research.

8. Act: Emergency act is declared in the sector of education, transportation, office, garments etc. system by the ministry of define sectors.

9. Free testing, free services: A special fund is managed to recover the patient by giving available free services at any cost.

General public:

1. Updated with awareness: People at all levels and all ages are must be awarded in the pandemic situation by the media (TV, Facebook or any others media).

2. Interest in Deposition: People can keep deposits in various insurance, associations, or banks so that cash money can help them in times of trouble. Moreover, there are opportunities to take a loan.

3. Learning and sharing in online: Participate in various online conferences to learn different techniques and sharing them among all people by the social online media in Facebook, Instagram or Twitter.

4. Mentality of Cooperation: If every rich person helps the poor and helpless people in the area, the poverty alleviation will be possible together with the Government and reach the target of zero hunger.

5. Humble Behavior: The general people should do its best to abide by all the rules because those being cautious may save their world from this calamity.

6. Immunity Capability: Healthy eating should be practiced to increase one's immunity. Only then it will be possible to deal against the affected of virus.

Defense Sector:

1. Emergency section: An appointment should be made in a section where all employees in defenses will be obliged to work in case of emergency.

2. Life insurance: If at least $5 \%$ of basic salary is deducted from the monthly salary of the members and emergency insurance is provided for them it will help him and his family.

Medical Service Sector:

1. Dedication level: The mentality of doctors and nurses to leave should be highest during the epidemic NGO, Private Sector:

1. Assist fund: Separate aid funds are needed only for epidemic relief and should be ensured that it reaches to all sectors people. It's applicable for the both NGO and private organization.

2. Salary Deposition policy: The authority has to take new measures during lockdown so that other industrial workers including garment workers do not fall into poverty. $5 \%$ of each month's salary was deducted and deposited in each worker's account. Media:

3. Online awareness: Making people aware through various talk shows, seminars, serials, and also cartoons.

4. Spread of communication: Through these, media can communicate a variety help among the all classes of people.

Victim:

1. Donation of plasma: Since antibodies are made in the body of a healed patient, his/her plasma can save the life of another dying person.

2. Share experience: The time from the very beginning treatment process should be share in Facebook or any media at any process. 
Table 6: Other responses that ought to be followed:

\begin{tabular}{|c|c|c|}
\hline Economy based response & Education based response & Social behavior, norm-based response \\
\hline $\begin{array}{l}\text { Both Govt. and private authority's } \\
\text { responsibility. }\end{array}$ & $\begin{array}{l}\text { Pre-preparation for online class in } \\
\text { all Education institutions. }\end{array}$ & A sprit of help and cooperation. \\
\hline $\begin{array}{l}\text { Appraisals Economist and remind } \\
\text { the GDP rate. }\end{array}$ & $\begin{array}{c}\text { So many courses and seminars are } \\
\text { organized and it will free for all } \\
\text { students }\end{array}$ & $\begin{array}{l}\text { To express the humanity through } \\
\text { principles, attitudes and behaviors. }\end{array}$ \\
\hline $\begin{array}{c}\text { Establishment of Additional aid } \\
\text { funds. }\end{array}$ & $\begin{array}{l}\text { Training or mentality growth can } \\
\text { be possible in medium of online. }\end{array}$ & $\begin{array}{c}\text { To share experience, suggestion and } \\
\text { advice among all. }\end{array}$ \\
\hline $\begin{array}{l}\text { Pre-preparation to exist in pandemic } \\
\text { period by overcoming the poverty. }\end{array}$ & "Emergency Students Aid funds". & \\
\hline
\end{tabular}

\section{CONCLUSIONS}

At the present time, there is currently no reliable estimation of how long the pandemic situation (COVID-19) will persist. Pandemic-related problems in Bangladesh, such as social distance, isolation, as well as in the sector of social and bad economic effects, may also cause psychological mediators act like depression, anxiety, rage/anger, anger, resentment, shame, helplessness, and loneliness. It is high time to adopt strategic and technical policy framework to control over the pandemic situation. The present crisis scenario is remarked in the sector of economic, health, education, and general public perception within mixed approach of meta-analysis and review article. To face with the pandemic situation and in the consideration of post covid-19 scenario a crisis management plan is proposed that divided into 10 major sectors. A committee is also recognized to manage and monitor the improvement of situation. For limitation, the proposed plan is not satisfied in all sectors. But in future are its bear a great significant importance for Gov. to control the epidemic situation in future. As the crisis response sector is declared its will be an easy way to manage emergency crisis scenario. The framework would stand for as a shield for the next possible contamination /spreading scenario or as a tool for preparing against the second wave of COVID-19. Not only this but this framework would also stand as a precaution for any further calamities that the country might face in the near future. But there are certain limitations of the research. As COVID-19 has been dispersed to almost all the possible sectors of daily lifestyle there were not enough scopes to address all the aspects also no beta testing about the committee was possible as the whole research was conducted sitting in front of the desk. Therefore, scope for further research on this is possible and open.

\section{REFERENCES}

Ahmed, M., 2020. Tertiary education during Covid-19 and beyond, [Online] Available at: https://www.thedailystar.net/opinion/news/tertiary-education-during-covid-19-and-beyond-1897321

Ahmed, Z., 2020. Coronavirus: Economy down, poverty up in Bangladesh, [Online] Available at: https://www.dw.com/en/coronavirus-economy-down-poverty-up-in-bangladesh/a-53759686

Ahorsu, D. K., Lin C., Imani V., Saffari M., Griffiths M., and Pakpour A., 2020. The Fear of COVID-19 Scale: Development and Initial Validation, International Journal of Mental Health and Addiction.

AlTakarli, N. S., 2020. China's Response to the COVID-19 Outbreak: A Model for Epidemic Preparedness and Management, Dubai Medical Journal, 3(2), pp. 44-49.

Azad, A. K., 2020. National Preparedness and Response Plan for COVID-19, Bangladesh, Dhaka: Directorate General of Health Services Health Service Division, Ministry of Health and Family Welfare.

Baker, S. R., Farrokhnia R.A., Meyer S., X, M., and Yannelis C., 2020. How Does Household Spending Respond to an Epidemic? Consumption during the 2020 COVID-19 Pandemic, The Review of Asset Pricing Studies.

Banna, M. H. A., Sayeed A., Kundu S., Christopher E., Hasan M.T., Begum M.R., Kormoker T., Dola S.T.I., Hassan M.M., Chowdhury S., and Khan M.S.I., 2020. The impact of the COVID-19 pandemic on the mental health of the adult population in Bangladesh: A nationwide cross-sectional study, International Journal of Environmental Health Research, pp. 1-25.

Berger, Z. D., Evans N. G., Phelan A. L., and Silverman R. D., 2020. Covid-19: Control measures must be equitable and inclusive, The British Medical Association, pp. 1-2.

Bhuiyan, A. A. M., 2020. Rethinking The Digitalization Of The Education System In Bangladesh, [Online] Available at: https://elearningindustry.com/rethinking-digitalization-education-system-in-bangladesh

Bhuiyan, A. K.M., Sakib N., Pakpour A.H., Griffiths M.D., and Mamun M.A., 2020. COVID-19-Related Suicides in Bangladesh Due to Lockdown and Economic Factors: Case Study Evidence from Media Reports, International Journal of Mental Health and Addiction, Issue May.

Bodrud-Doza, M., Shammi M., Bahlman L., Islam A.R.M.T., and Rahman M.M., 2020. Psychosocial and SocioEconomic Crisis in Bangladesh Due to COVID-19 Pandemic: A Perception-Based Assessment, Frontiers in Public Health.

Centers for Disease Control and Prevention, 2007. Interim Pre-pandemic Planning Guidance : Community Strategy for Pandemic Influenza Mitigation in the United States - Interim Pre-Pandemic Planning Guidance : Community Strategy for Pandemic Influenza Mitigation in the United States, CDC stacks. 
Chowdhury, H. R., 2020. The poor in North Bangladesh are the worst victims of Covid-19 fallout, [Online] Available at: https://www.thedailystar.net/opinion/news/the-poor-north-bangladesh-are-the-worst-victimscovid-19-fallout-1937717

Cirrincione, L., Plescia F., Ledda C., Rapisarda V., Martorana D., Moldovan R.E., Theodoridou K., and Cannizzaro E., 2020. COVID-19 Pandemic: Prevention and protection measures to be adopted at the workplace, Sustainability (Switzerland), 12(9), 1-18.

Daszak, P., Olival K. J., and Li, H., 2020. A strategy to prevent future epidemics similar to the 2019-nCoV outbreak, Biosafety and Health, 2(1), pp. 6-8.

DATABD, 2020. COVID-19 in Bangladesh: A Visual Guide to the Economic Impact, [Online] Available at: https://databd.co/stories/covid-19-in-bangladesh-a-visual-guide-to-the-economic-impact-11064

Directorate General of Health Services, Ministry of Health, ICT Division, 2020. COVID-19 Telehealth Center Daily Report.

DU Correspondent, 2020. Dhaka University is not interested in going to online classes thinking of students, https://www.banglatribune.com/others/news/622416?_cf_chl_captcha_tk=fd869fe1de9546694ae4087814a 61ebf8a12d322-1600266938-0-AQEF8IqKQwDbKRYQXxrEFzRVk69ffgf0dfWipvRPs8-688wBpdc42 YOO pQhiE1MAv5hmUMM-UnL8Atn_aR8sbDNxIoBuLQAJ 1xTQlytDIDhvHKwhkbdUJfuVSTfIvSkM mpV

Emmungil , L., and Akleylek S., 2008. Technical Requirements for Online Education Support, pp. 607-609.

Etzold, B., and Mallick B., 2015. Bangladesh at a Glance, Country Profile: Focus migration.

Fernandes, N., 2020. Economic effects of coronavirus outbreak ( COVID-19) on the world economy Nuno Fernandes Full Professor of Finance IESE Business School Spain, SSRN Electronic Journal, pp. 0-29.

Global Influenza Program, 2005. Pandemic Influenza Preparedness and Response, A WHO guidance document,: WHO.

Goldman-Mellor, S. J., Saxton K. B., and Catalano R. C., 2010. Economic contraction and mental health: A review of the evidence, 1990-2009, International Journal of Mental Health, 39(2), pp. 6-31.

Greenberg, N., Docherty M., Gnanapragasam S., and Wessely S., 2020. Managing mental health challenges faced by healthcare workers during covid-19 pandemic, The BMJ, 368(March), pp. 1-4.

Gudmundsson, R., 2020. Helping Bangladesh Recover from COVID-19, [Online] Available at: https://www. imf.org/en/News/Articles/2020/06/11/na-06122020-helping-bangladesh-recover-from-covid-19

Hossain, M. A., Hossain K.M.A., Walton L.M., Uddin Z., Haque M.O., Kabir M.F., Arafat S.M.Y., Sakel M., Faruqui R., Jahid I.K., and Hossain Z., 2020. Knowledge, Attitudes, and Fear of COVID-19 during the Rapid Rise Period in Bangladesh, medRxiv.

Islam, M. S., Amin M., Salman M., and Tanvir K., 2020. Online classes for university students in Bangladesh during the Covid-19 pandemic- is it feasible?, [Online] Available at: https://tbsnews.net/ thoughts/ online-classesuniversity-students-bangladesh-during-covid-19-pandemic-it-feasible-87454

Islam, S. T., and Divadkar, Y. N., 2020. How Bangladesh's leaders should respond to the economic threats of COVID-19,[Online] Available at: https://www.weforum.org/agenda/2020/04/covid-19-coronavirusbangladesh/

Jamal, E. O., 2020. How three economic impacts of Covid-19 could spell danger for Bangladesh, [Online] Available at: https://www.thedailystar.net/opinion/the-overton-window/news/how-three-economic-impactscovid-19-could-spell-danger-bangladesh-1929277

Kamol, E., 2020. Disparity in education to increase for COVID-19: experts, [Online] Available at: https://www.newagebd.net/article/106737/disparity-in-education-to-increase-for-covid-19-experts

KPMG, 2020. Bangladesh Government and institution measures in response to COVID-19, https://home.kpmg/ xx/en/home/insights/2020/04/bangladesh-government-and-institution-measures-in-response-to-covid.html

Kuckertz, A., Brändle L., Gaudig A., Hinderer S., Morales Reyes C.A., Prochotta A., Steinbrink K.M., and Berger, E.S.C., 2020. Startups in times of crisis - A rapid response to the COVID-19 pandemic, Journal of Business Venturing Insights, 13(April).

Liu, S., Yang L., Zhang C., Tao Y., Liu Z., Hu S., and Zhang, B., 2020. Online mental health services in China during the COVID-19 outbreak, The Lancet Psychiatry.

Mamun, M. A., Bodrud-Doza M., and Griffiths M. D., 2020. First COVID-19 suicide case in Bangladesh due to fear of COVID-19 and xenophobia: Possible suicide prevention strategies, Asian Journal of Psychiatry, 51, 2-3.

Mamun, M. A., Bodrud-Doza M., and Griffiths, M. D., 2020. Hospital suicide due to non-treatment by healthcare staff fearing COVID-19 infection in Bangladesh?, Asian Journal of Psychiatry, Volume 54.

Mamun, M. A., Chandrima R. M., and Griffiths M. D., 2020. Mother and Son Suicide Pact Due to COVID-19-Related Online Learning Issues in Bangladesh: An Unusual Case Report, International Journal of Mental Health and Addiction, pp. 1-4.

Mamun, M. A., and Griffiths M. D., 2020. First COVID-19 suicide case in Bangladesh due to fear of COVID-19 and xenophobia: Possible suicide prevention strategies, Asian Journal of Psychiatry, pp. 2-3.

MICS, 2020. Bangladesh MICS 2019 Report: Key Findings, [Online] Available at: https://mics.unicef.org/news_entries/ 152/BANGLADESH-MICS-2019-REPORT:-KEY-FINDINGS

Moin, A. T., Sakib M. N., Araf Y., and Sarkar B., 2020. Combating COVID-19 Pandemic in Bangladesh: A Memorandum from Developing Country.

Moore, S. E., and Okyere E., 2020. Controlling the Transmission Dynamics of COVID-19, pp. 1-13. 
Mowbray, H., 2020. In andBeijing, coronavirus 2019-nCoV has created a siege mentality, The BMJ, 368, 1-2.

Perlman, S., 2020. Another decade, another coronavirus, New England Journal of Medicine, pp. 760-762.

Pesek, W., 2020. Bangladesh banking: Covid overwhelms Dhaka's weak system, https://www.euromoney. com/article/b1 m212jp2q958m/bangladesh-banking-covid-overwhelms-dhakas-weak-system

Peter, E., and Roberts M., 2016. Leveraging Urbanization in South Asia : Managing Spatial Transformation for Prosperity and Livability, Washington, DC: World Bank.

Prem, K., Liu Y., Russell T.W., Kucharski A.J., Eggo R.M., Davies N., Flasche S., Clifford S., Pearson C.A.B., Munday J.D., Abbott S., Gibbs H., Rosello A., Quilty B.J., Jombart T., Sun F.,Diamond C., Gimma A., van Zandvoort K., Funk S., Jarvis C.I., Edmunds W.J., Bosse N.I., Hellewell J., Jit M., and Klepac P., 2020. The effect of control strategies to reduce social mixing on outcomes of the COVID-19 epidemic in Wuhan, China: a modelling study, The Lancet Public Health.

Raihan, S., 2020. [Online] Available at: https://www.thedailystar.net/opinion/news/covid-19-and-the-challengestrade- bangladesh-1956405

Raihan, S., 2020. Covid-19 induced economic crisis in Bangladesh: What needs to be done?, Available at: https:// tbsnews.net/analysis/covid-19-induced-economic-crisis-bangladesh-what-needs-be-done-80197

Ramij, M., and Sultana A., 2020. Preparedness of Online Classes in Developing Countries amid COVID-19 Outbreak: A Perspective from Bangladesh, SSRN Electronic Journal.

Salihu, H. M., Dongarwar D., Aliyu M. H., and Azuine R. E., 2020. Global Ranking of COVID-19-Related Mortality by Country using a Novel Pandemic Efficiency Index (PEI), International Journal of Maternal and Child Health and AIDS (IJMA), 9(2), pp. 182-185.

Shammi, M., Bodrud-Doza M., Islam A. R. M. T., and Rahman M. M., 2020. Strategic assessment of COVID-19 pandemic in Bangladesh: comparative lockdown scenario analysis, public perception, and management for sustainability, Springer.

Taylor, J., 2020. How Dhaka's urban poor are dealing with COVID-19, [Online] Available at: https://www.iied.org/how-dhakas-urban-poor-are-dealing-covid-19

Uddin , M., 2020. Effects of the pandemic on the education sector in Bangladesh, https://thefinancialexpress.com.bd /views/effects-of-the-pandemic-on-the-education-sector-in-bangladesh-1592061447

World Food Programme, 2020. WFP and Government of Bangladesh deliver high-energy biscuits to school children affected by COVID-19 school closures, [Online] Available at: https://reliefweb.int/report/ bangladesh/wfpand-government-bangladesh-deliver-high-energy-biscuits-school-children

World Health Organization, 2020. Coronavirus Disease (COVID-19) Weekly Epidemiological Update Data, https://www. who.int/docs/default-source/coronaviruse/situation-reports/20200907-weekly-epi-update 4.pdf?sfvrsn=f5f607ee_2

World Health Organization, 2020. Morbidity and Mortality Weekly Update, [Online] Available at: https://www.who.int /bangladesh/emergencies/coronavirus-disease-(covid-19)-update/

World Health Organization, 2020. Naming the coronavirus disease (COVID-19) and the virus that causes it, [Online] Available at: https://www.who.int/emergencies/diseases/novel-coronavirus-2019/technical-guidance/naming -the-coronavirus-disease-(covid-2019)-and-the-virus-that-causes-it

World Health Organization, 2020. WHO Bangladesh COVID-19 Morbidity and Mortality Weekly Update (MMWU)

World Health Organization, 2020. WHO Director-General's opening remarks at the media briefing on COVID-19 - 11 March 2020, [Online] Available at: https:/www.who.int/dg/speeches/detail/who-director-general-s-openingremarks-at-the-media-briefing-on-covid-19---11-march-2020

worldometer, 2020. COVID-19 Coronavirus Pandemic, [Online] Available at: https:/www.worldometers.info/ coronavirus/?utm_campaign=homeAdvegas $1 \% 3 \mathrm{~F} \% 22 \& \mathrm{fbclid}=$ IwAR1WP5w31h5kkeKiDd9ENKV6H9K63 K cOVp5DUDg-1vOjdYc-HaeB31dp718

Zabala, 2020. Measures taken by the European countries against COVID-19, [Online] Available at: https://www.zabala.eu/en/news/measures-taken-european-countries-against-covid-19.

(C) 2020 The Authors. Journal of Engineering Science published by Faculty of Civil Engineering, Khulna University of Engineering \& Technology. This is an open access article under the terms of the Creative Commons AttributionNonCommercial-NoDerivatives License, which permits use and distribution in any medium, provided the original work is properly cited, the use is non-commercial and no modifications or adaptations are made. 